\title{
Moesin Expression Is Associated with Glioblastoma Cell Proliferation and Invasion
}

\author{
QING WANG ${ }^{1}$, XIAOJIE LU ${ }^{1}$, SHIDI ZHAO ${ }^{1}$, MINGZHI PANG ${ }^{1}$, XUECHAO WU ${ }^{1}$, HENG WU $^{2}$, \\ ROBERT M. HOFFMAN ${ }^{3,4}$, ZHIJIAN YANG $^{2}$ and YAN ZHANG ${ }^{1}$ \\ ${ }^{1}$ Department of Neurosurgery, Neuroscience Center, \\ Affiliated Wuxi Second Hospital of Nanjing Medical University, Wuxi, P.R. China; \\ ${ }^{2}$ Origin Biosciences Inc., Nanjing, P.R. China; \\ ${ }^{3}$ AntiCancer, Inc., San Diego, CA, U.S.A.; \\ ${ }^{4}$ Department of Surgery, University of California, San Diego, CA, U.S.A.
}

\begin{abstract}
Aim: To investigate the effect of moesin expression on cell proliferaton and invasion of human glioblastoma cell lines in vitro. Materials and Methods: Glioblastoma LN229 and U87 cells were transfected with the H4645-plenti-EGFP-moesin expression vector for moesin up-regulation. Moesin and $\beta$ catenin expression levels in the transfected cells were analyzed by real-time polymerase chain reaction $(P C R)$ and Western blotting. Cell proliferation was measured using the CCK8 assay. Cell invasion and migration ability were assessed using a transwell cell invasion and wound-healing assay. Results: Moesin $m R N A$ and protein expression were significantly increased in the two transfected LN229-H4645 and U87-H4645 cell lines. $\beta$-catenin expression was increased by moesin upregulation in the transfected LN229-H4645 and U87-H4645 cell lines. The CCK-8 assay revealed that up-regulating moesin results in a significant increase in glioblastoma cell proliferation. Glioblastoma cell invasion and migration were increased by moesin up-regulation. Conclusion: Up-regulation of moesin expression in glioblastoma cells correlated with increases in cell proliferation, invasion and migration, suggesting moesin's role in glioblastoma progression.
\end{abstract}

Glioblastoma is a highly invasive recalcitrant cancer that is poorly understood (1-9). Moesin is a member of the ezrinradixin-moesin (ERM) protein family and is a link between the

This article is freely accessible online.

Correspondence to: Qing Wang, Department of Neurosurgery, Neuroscience Center, Affiliated Wuxi Second Hospital of Nanjing Medical University, Wuxi, Jiangsu Province, P.R. China. Tel: +86 51068562741, Fax: +86 51068562052, e-mail: wxwqnj@163.com

Key Words: Moesin, up-regulation, silencing, proliferation, invasion, glioblastoma, in vitro. actin cytoskeleton and the plasma membrane. Moesin is involved in cell morphology, motility and adhesion, as well as other processes of tumorigenesis (10-12). Moesin has been studied in estrogen receptor (ER)-negative breast cancers (13), basal breast carcinomas (14), pancreatic cancer (15), melanoma (16), and gastric carcinoma (17). Moesin expression correlated with pathologic grade and poor clinical outcome, including survival in astrocytoma $(18,19)$. However, the role of moesin in human glioblastoma progression is incompletely understood and, thus, the topic of the present report.

In this study, we investigated moesin's effect on the growth and invasion ability of the glioblastoma cells by upregulation of the gene $(M S N)$.

\section{Materials and Methods}

Cell culture. The glioblastoma cell line LN229 and U87 were purchased from the Shanghai cell bank of the Chinese Academy of Sciences (Shanghai, China). The cells were cultured in RPMI 1640 medium (GIBCO Life Technologies, Grand Island, NY, USA) containing $10 \%$ fetal bovine serum (Thermo Fisher Scientific, Waltham, MA, USA), $100 \mathrm{U} / \mathrm{ml}$ penicillin and $100 \mu \mathrm{g} / \mathrm{ml}$ streptomycin (Thermo Fisher Scientific) at $37^{\circ} \mathrm{C}$ with $5 \% \mathrm{CO}_{2}$.

Moesin-expression vector transfection. The H4645-plenti-enhanced green fluorescent protein (EGFP)-moesin expression vector was used for up-regulation of the moesin gene (MSN) in the LN229 and U87 glioblastoma cells (LN229-H4645 and U87-H4645, respectively). The H149 plenti-EGFP empty vector was used as negative control (LN229-H149 and U87-H149, respectively). The moesin expression vector was constructed by Obio Technology Corp., Ltd. (Shanghai, China). Cultured glioblastoma LN229 and U87 cells were transfected with the moesin expression vector according to the manufacturer's instructions. After $24 \mathrm{~h}$ transfection, the medium was changed. Cells were then observed under fluorescence microscopy at 48 hours after transfection. Cells were selected and treated with $500-800 \mu \mathrm{g} / \mathrm{ml}$ G148 (Micropoly Biotech Co., Ltd, Nanjing, China) for 1 week. Images were obtained from fluorescence microscopy. Transfection efficiency of the expression vector in the two cell lines was 

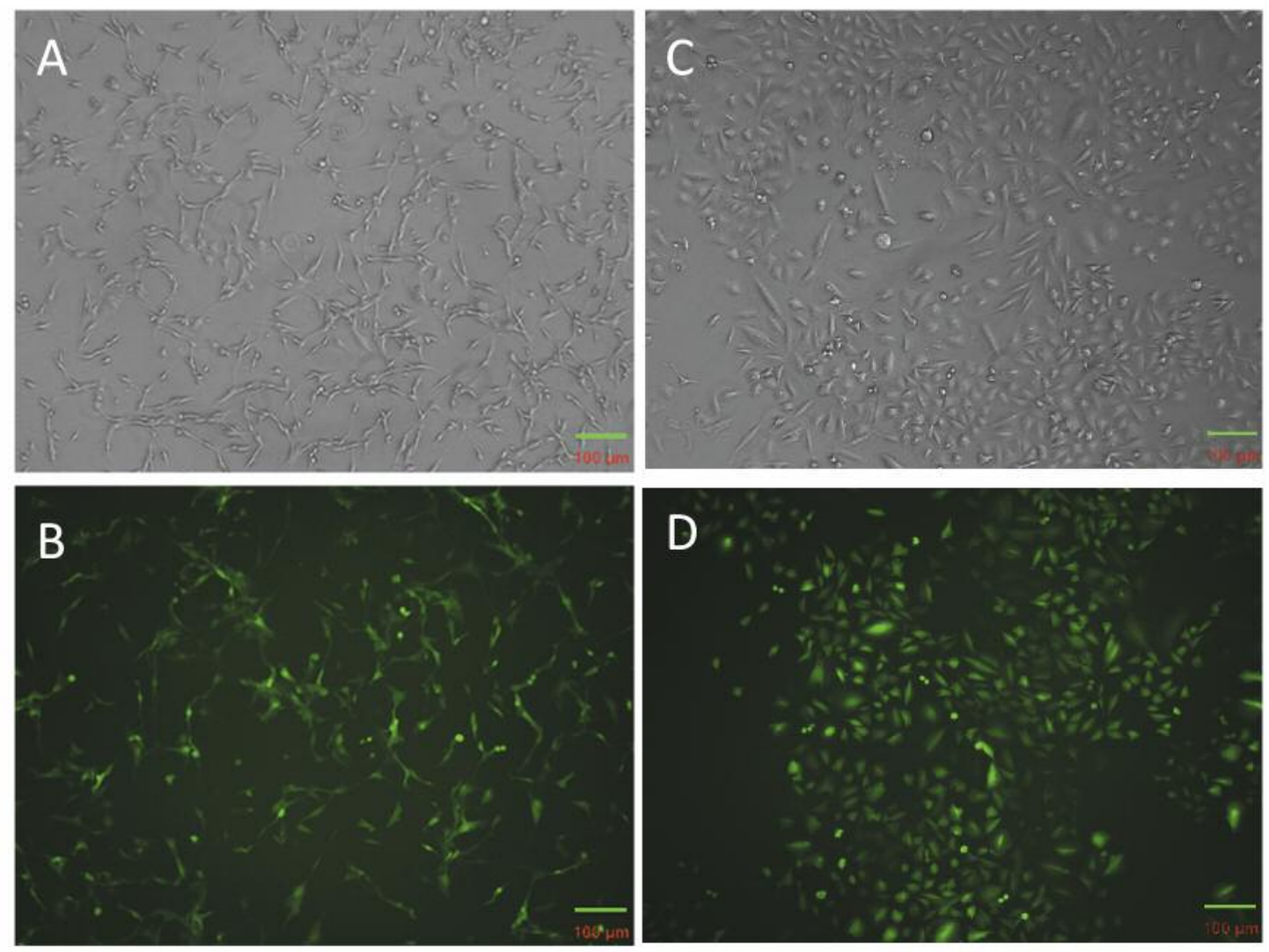

Figure 1. Moesin-expression-vector transfection of glioblastoma cells. (A) Bright-field imaging of untransfected U87 cells. (B) Fluorescence imaging of U87 cells transfected with the H4645-plenti-EGFP-moesin expression vector (U87-H4645). (C) Bright-field imaging of untransfected LN229 cells. (D) Fluorescence imaging of LN229 cells transfected with the H4645-plenti-EGFP-moesin expression vector (LN229-H4645). All images were obtained at $\times 200$ magnification.

confirmed based on up-regulation of moesin expression by real-time polymerase chain reaction (PCR) and Western blotting analysis.

Isolation of RNA and reverse transcription-polymerase chain reaction $(R T-P C R)$. Total RNA was isolated from cell lines with the Trizol reagent (Invitrogen, Carlsbad, CA, USA) and reversely transcribed using a PrimeScript RT-PCR kit (Takara, Shimogyo-ku, Kyoto, Japan) according to the manufacturer's instructions, followed by PCR amplification with specific primers. The following primers were used to amplify most of the coding region of moesin $(M S N)$ (sense, 5' CAGCATCAAGAACAAGAAAGGC 3'; and antisense, 5'GGGGAG CATAGAAGACGAAG-3'), $\beta$-catenin (CTNNB1) (sense, 5' GCCA CAAGATTACAAGAAACGG-3'; and antisense, 5' ATCCACC AGAGTGAAAAGAACG-3') and glyceraldehyde 3-phosphate dehydrogenase $(G A P D H)$ (sense, 5'-GCACCGTCAA GGCTGA GAAC-3'; and antisense, 5'-TGGTGAAGACGCCA GTGGA-3').

Quantitative real-time PCR was performed using a 7300 real-time PCR system (Applied Biosystems, Waltham, MA, USA). PCR was carried out in a volume of $20 \mu \mathrm{l}$, containing $10 \mu \mathrm{l} 2 \times$ qPCR Master Mix, $2 \mu \mathrm{l}$ cDNA, $0.2 \mu \mathrm{l}$ of each primer and $0.4 \mu \mathrm{l}$ ROX reference dye 1 . Reaction conditions for amplification of target genes were one cycle of denaturation at $95^{\circ} \mathrm{C}$ for 5 minutes; followed by 40 cycles of 5 seconds degeneration at $95^{\circ} \mathrm{C} ; 30$ seconds annealing at $60^{\circ} \mathrm{C}$; and 40 seconds prolongation at $72^{\circ} \mathrm{C}$. Data were analyzed by the relative standard curve method and normalized for $G A P D H$ expression. Relative RNA expression was calculated using the $2^{-\Delta \Delta \mathrm{Ct}}$ method. All samples were performed in triplicate.

Western blotting. Moesin and $\beta$-catenin protein expression in transfected cells was analyzed by Western blotting. Cells were lysed in $100 \mu \mathrm{l}$ radio-immunoprecipitation assay (RIPA) lysis buffer (50 mmol/l Tris-HCl, pH 7.5, $1 \%$ NP-40, 150 mmol/l NaCl, $1 \mathrm{mg} / \mathrm{ml}$ aprotinin, $1 \mathrm{mg} / \mathrm{ml}$ leupeptin, $1 \mathrm{mmol} / 1 \mathrm{Na}_{3} \mathrm{VO}_{4}, 1 \mathrm{mmol} / 1 \mathrm{NaF}$ ) at $4^{\circ} \mathrm{C}$ for $30 \mathrm{~min}$. Cell debris was removed by centrifugation at $12,000 \times \mathrm{g}$ for $20 \mathrm{~min}$ at $4^{\circ} \mathrm{C}$. Protein concentration was determined with the Bradford assay (Bio-Rad, Hercules, CA, USA). An equal amount of lysate $(40 \mu \mathrm{g})$ was resolved with sodium dodecyl sulfate (SDS)polyacrylamide gel electrophoresis (PAGE) and transferred to a polyvinylidene difluoride membrane (Millipore, Bedford, MA, USA). The membranes were blocked with 5\% nonfat milk at room temperature for $1 \mathrm{~h}$ and then incubated for $2 \mathrm{~h}$ with primary antibodies to moesin, $\beta$-catenin or $\beta$-actin (Cell Signaling Technology, Boston, MA, USA). The membranes were then incubated for $1 \mathrm{~h}$ with an appropriate horseradish peroxidase-linked secondary antibody (Santa Cruz Biotechnology, Dallas, TX, USA). Electrochemiluminescence was performed according to the manufacturer's instructions using a 

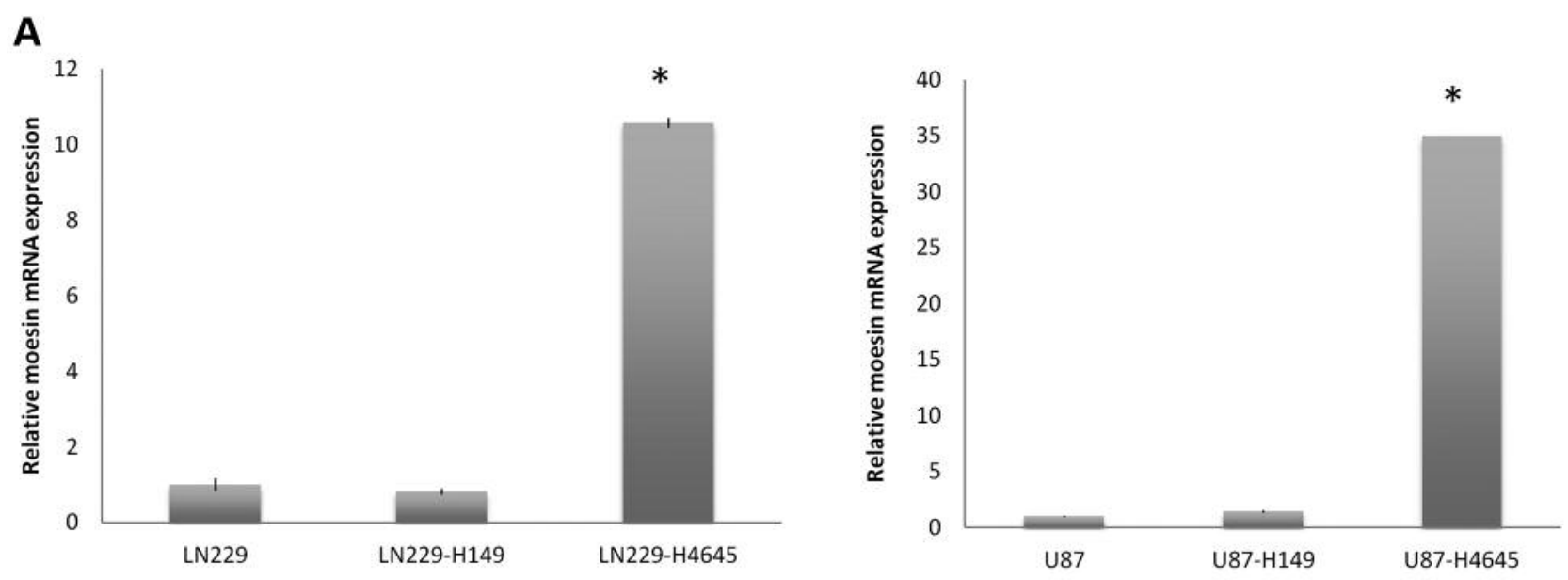

B

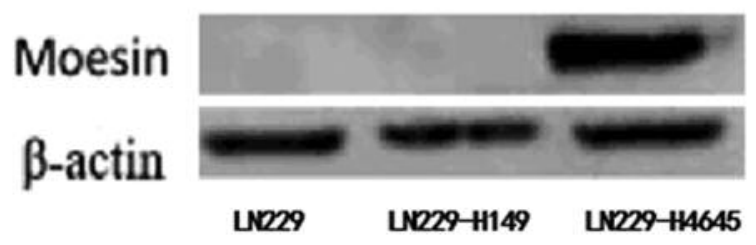

Moesin

$\beta$-actin

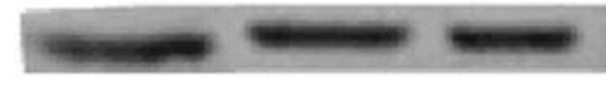

$\mathbf{U 8 7}$

U87-1149

U87-\$4645
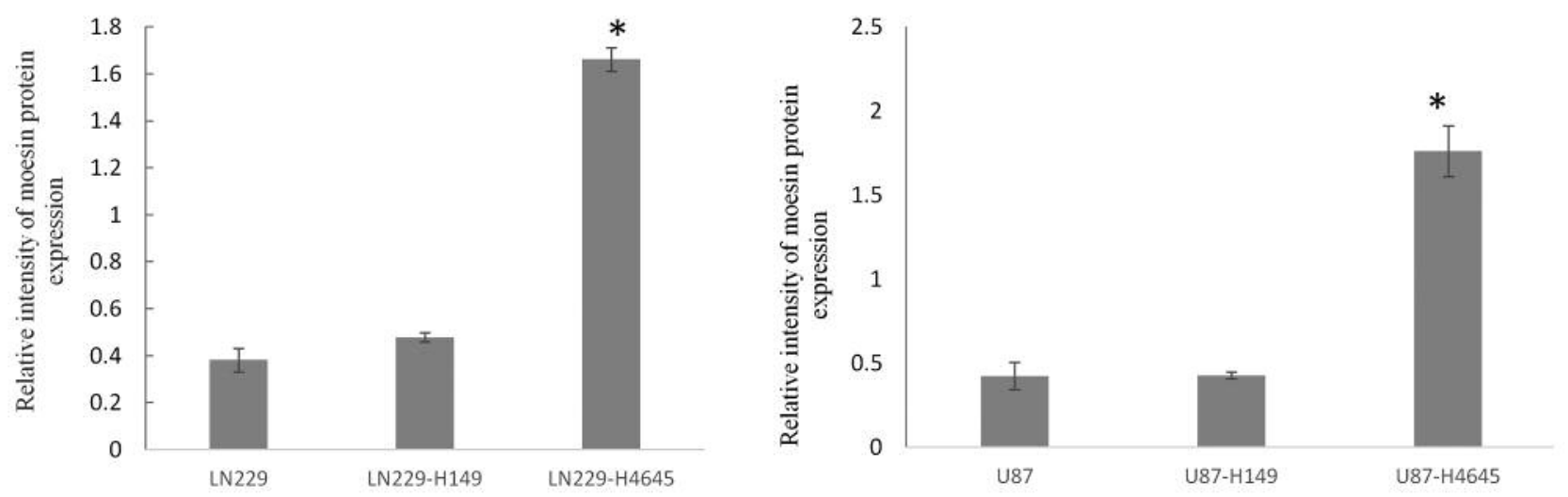

Figure 2. Moesin up-regulation in glioblastoma cells. (A) Moesin mRNA expression in LN229, LN229-H149 (vector control) and LN229-H4645 cells (left graph); and U87, U87-H149 (vector-control) and U87-H4645 cells (right graph). (B) Moesin protein expression in LN229, LN229-H149 and LN229H4645 cells (left panel); and U87, U87-H149 and U87-H4645 cells (right panel). ${ }^{*} p<0.01$, when compared with untransfected and vector control cells.

ChemiDoc $^{\text {TM }}$ Touch imaging system (Bio-Rad). Quantity-One software (Bio-Rad) was used to quantify the density of bands.

Cell proliferation assay. Cell proliferation was measured using the CCK8 assay. Untransfected and transfected cells $\left(3 \times 10^{3}\right)$ were transferred to each well of a 96-well plate in RPMI 1640 containing $10 \%$ FBS. Five duplicate wells were set up for each cell group and the test was repeated 3 times. After 24, 48 and 72 hours of incubation, each well was supplemented with $10 \mu \mathrm{l}$ CCK8 reagent for $4 \mathrm{~h}$. The optical density (OD) at a wavelength of $450 \mathrm{~nm}$ was determined with a microplate reader (Bio-Rad). Proliferation curves were plotted for each of the cell groups.

Transwell cell invasion assays. For the invasion assays, the upper transwell chamber of an insert was coated with $20 \mu \mathrm{l} 20 \%$ Matrigel (Becton Dickinson (BD), Franklin Lakes, NJ, USA) in RPMI1640 medium. After drying for $2 \mathrm{~h}$, untransfected and transfected cells $\left(1 \times 10^{5}\right.$ cells/well $)$ in $200 \mu \mathrm{l}$ serum-free media were seeded onto the 

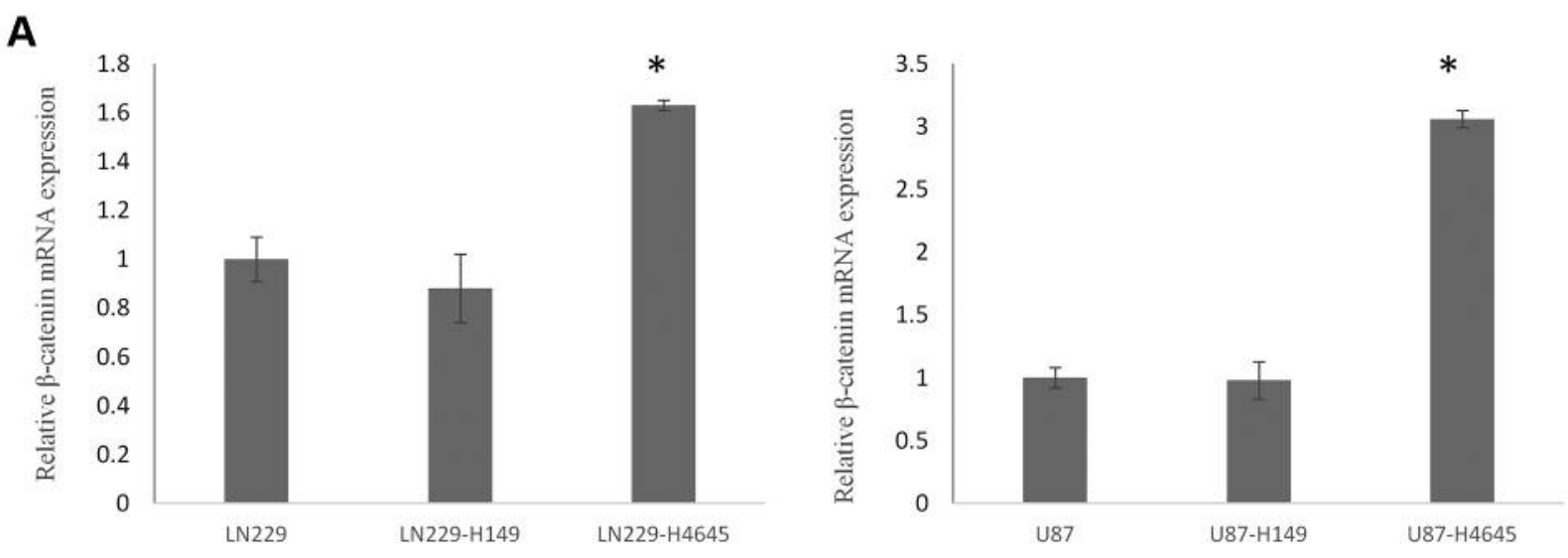

B

\section{B-catenin}

及-actin

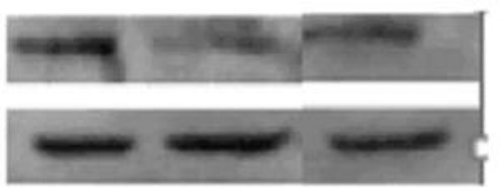

U1229-14645 U1229-1149 U1229

\section{B-catenin}

B-actin

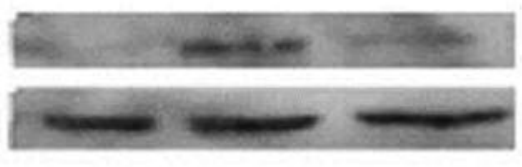

$\mathbf{4 8 7}$

U87-14645
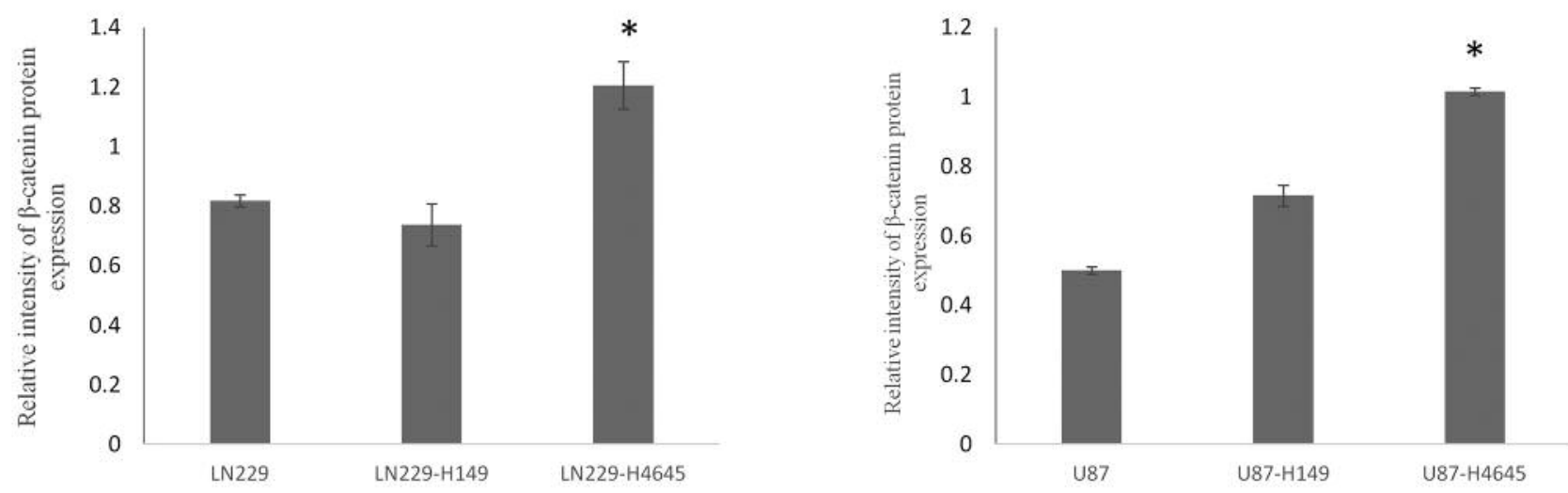

Figure 3. Effect of moesin up-regulation on glioblastoma $\beta$-catenin expression. (A) $\beta$-catenin mRNA expression in LN229, LN229-H149 and LN229H4645 cells (left graph); and U87, U87-H149 and U87-H4645 cells (right graph). (B) $\beta$-catenin protein expression in LN229, LN229-H149 and LN229-H4645 cells (left panel); and U87, U87-149 and U87-H4645 cells (right panel). * $p<0.01$, when compared with untransfected and vectorcontrol cell group.

upper chamber coated by Matrigel. Medium (600 $\mu \mathrm{l})$ containing $10 \%$ FBS was added to the lower chamber. After $48 \mathrm{~h}$ incubation, cells were washed with PBS 2 times and fixed with ethanol for 20 $\mathrm{min}$. The cells remaining on the upper membrane were removed with cotton wool, whereas the cells that had invaded through the membrane were stained with crystal violet. After staining, cells on the back of the transwell membrane were imaged and counted using an inverted microscope (Olympus BX53; Olympus, Tokyo, Japan). Wound healing assay. For wound-healing assays, $1.5 \times 10^{5}$ untransfected or transfected cells were plated in 12-well plates for $24 \mathrm{~h}$. Similar-sized wounds were created in monolayers of cells by scraping a gap using a micropipette tip. After removing cell debris by rinsing with phosphate-buffered saline, fresh medium was added. Reference points were marked using a scalpel on the outer surface of the dish. The cells started migrating from the edge of the wound and repopulated the gap area. Cells were then observed for 'wound closure' at $24 \mathrm{~h}$ and $48 \mathrm{~h}$ under a light microscope. Images at each time point were obtained (magnification, $\times 40$ ). Image J Software (NIH, Bethesda, MD, USA) was used for analysis and quantification of the healing rate. The wound area closure was measured at three independent wound sites per group. For comparison of each cell group, analysis at $24 \mathrm{~h}$ was selected because maximal differences 

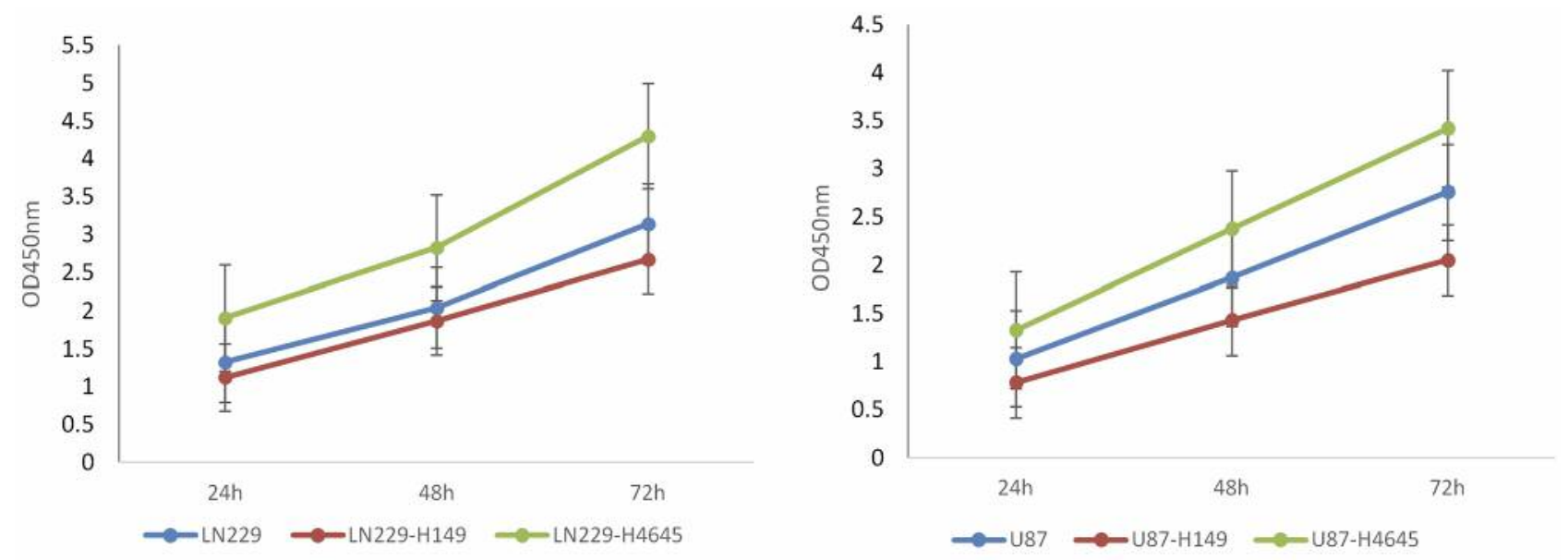

Figure 4. Effect of moesin up-regulation on glioblastoma cell proliferation. (A) Cell proliferation curves for LN229 cell groups (LN229, LN229H149, LN229-H4645). (B) Cell proliferation curves for U87, U87-H149, U87-H4645.

between groups were observed at this time. The wound-healing rate was calculated as follows: (0-hour wound area -24-hour wound area) $/ 0$ hour wound area $\times 100 \%$.

Statistical analysis. Statistical analysis was performed using SPSS16.0 software (SPSS Inc., Chicago, IL, USA). All results are expressed as mean \pm SD. Comparisons between two groups were made with the Student's $t$-test. $P<0.05$ was considered significant.

\section{Results and Discussion}

Moesin up-regulation in glioblastoma cells. Moesin upregulation was achieved by transfecting glioblastoma cell lines U87 and LN229 with the H4645-plenti-EGFP-moesin expression vector (Figure 1B and E). The expression level of moesin mRNA ( $M S N$ mRNA) was significantly increased in the transfected LN229-H4645 and U87-H4645 cells as compared to untransfected cells and vector control (LN229H149 and U87-H149) $(p<0.01)$ (Figure 2A). The protein expression level of moesin was also significantly increased in transfected LN229-H4645 and U87-H4645 cells as compared to untransfected and vector control cells $(p<0.01)$ (Figure 2B).

Effect of moesin up-regulation on $\beta$-catenin expression in glioblastoma cells. $\beta$-catenin expression was analyzed to investigate the potential mechanisms underlying the biological effect of moesin up-regulation in glioblastoma cells. The data showed that $\beta$-catenin mRNA (CTNNB1 mRNA) expression was increased by moesin up-regulation in transfected LN229H4645 and U87-H4645 cells compared with the untransfected and vector controls $(p<0.01)$ (Figure $3 \mathrm{~A})$.

The up-regulation of moesin expression also resulted in increased protein expression of $\beta$-catenin in the LN229-
H4645 and U87-H4645 cells as compared with the untransfected and vector controls $(p<0.01)$ (Figure 3B).

Effect of moesin up-regulation on glioblastoma cell proliferation. The CCK- 8 assay was used to assess the potential effects of moesin up-regulation and silencing on cell proliferation. Cell proliferation was monitored up to 72 hours. Moesin up-regulation in the transfected LN229-H4645 and U87-H4645 cells significantly increased cell proliferation from $48 \mathrm{~h}$ as compared with the untransfected and vector controls (LN229-H149 and U87-H149) $(p<0.01)$ (Figure 4).

Effect of moesin up-regulation in cell glioblastoma invasion and migration. Cell invasion was examined with the transwell assay. The number of cells migrating to the lower chamber was significantly increased by moesin up-regulation in the transfected LN229-H4645 and U87-H4645 cells as compared with the untransfected and vector controls (LN229-H149 and U87-H149, respectively) ( $p<0.01)$ (Figure 5).

These results were further verified using the wound-healing assay. Both moesin-up-regulated LN229-H4645 and U87H4645 cells demonstrated significantly higher cell migration compared to the untransfected and vector controls (LN229H149 and U87-H149, respectively) ( $p<0.01)$ (Figure 6).

Moesin is a cytoskeletal protein that appears to affect cytoskeletal assembly between the cytoplasmic side of the cell membrane and the nuclear skeleton, which would facilitate cell invasion $(17,22)$. In the present study, we found that $\beta$-catenin expression was affected by moesin expression in glioblastoma cells, suggesting involvement of $\beta$-catenin in moesin's effects on glioblastoma-cell proliferation and invasion. The results of the present report indicate that 

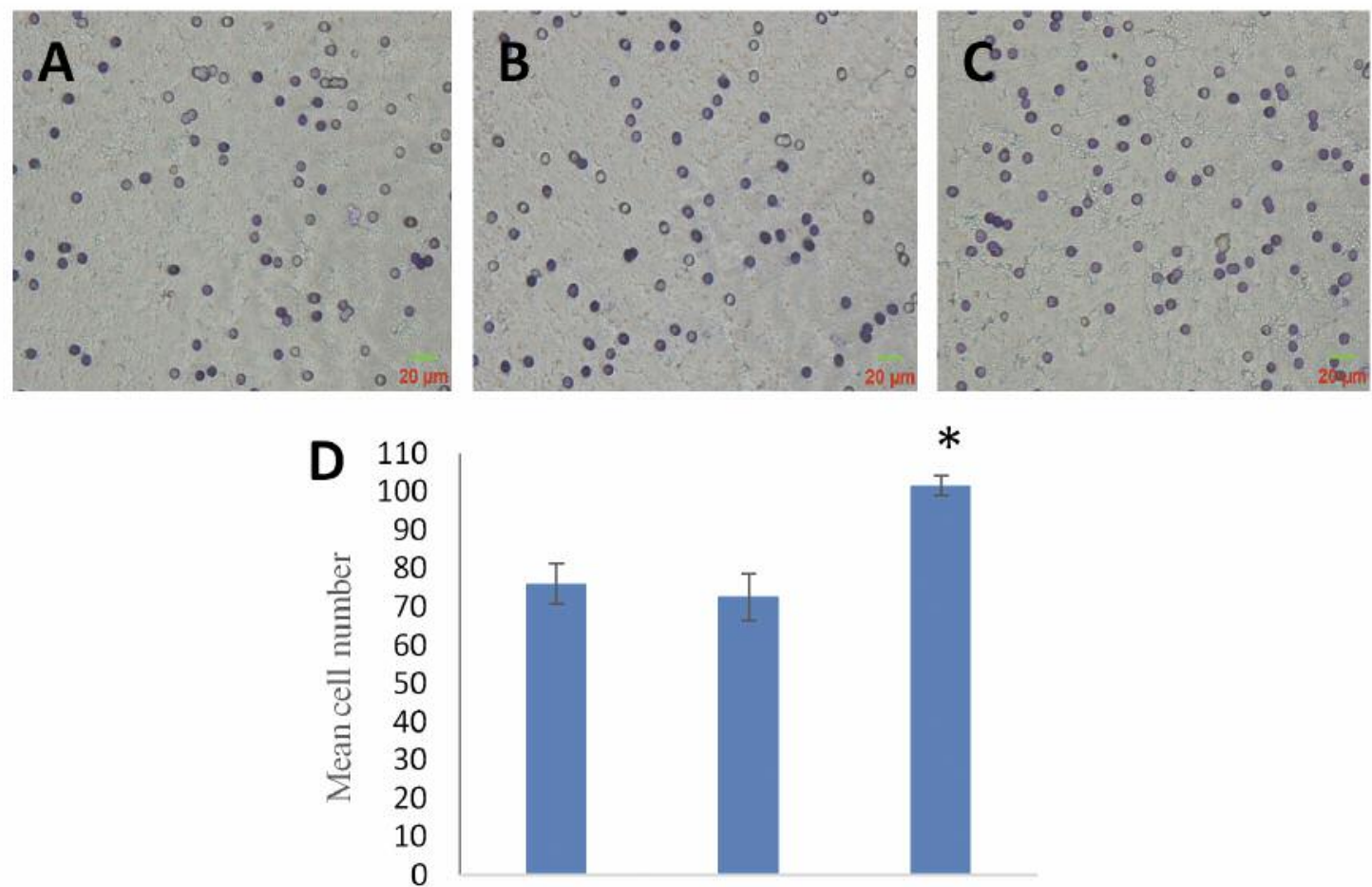

$*$

I

(1)

100
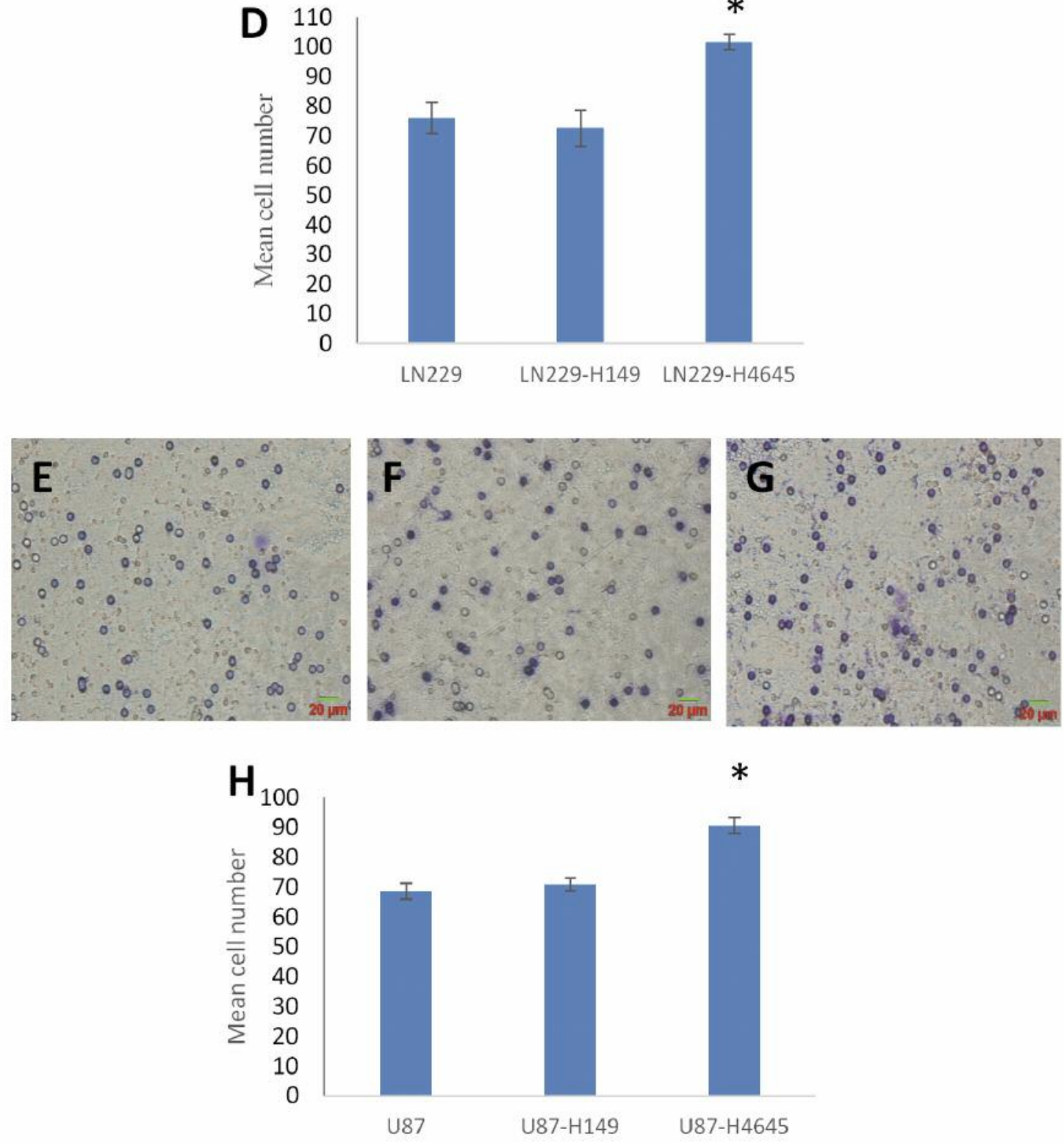

$*$

Figure 5. Effect of moesin up-regulation on glioblastoma cell invasion and migration in the transwell assay. Effect of moesin up-regulation on cell invasion and migration of glioblastoma cells, (A), (B) and (C). Representative images of migrating LN229, LN229-H149 and LN229-H4645 cells, respectively. (D) Quantification of the migrating cells in each LN229 group; $(E),(F)$ and $(G)$. Representative images of migrating U87, U87-H149 and U87-H4645 cells, respectively; $(H)$. Quantification of the migrating cells in each U87 group. All images were observed at $\times 400$ magnification. ${ }^{*} p<0.01$, when compared with untransfected and vector controls. 

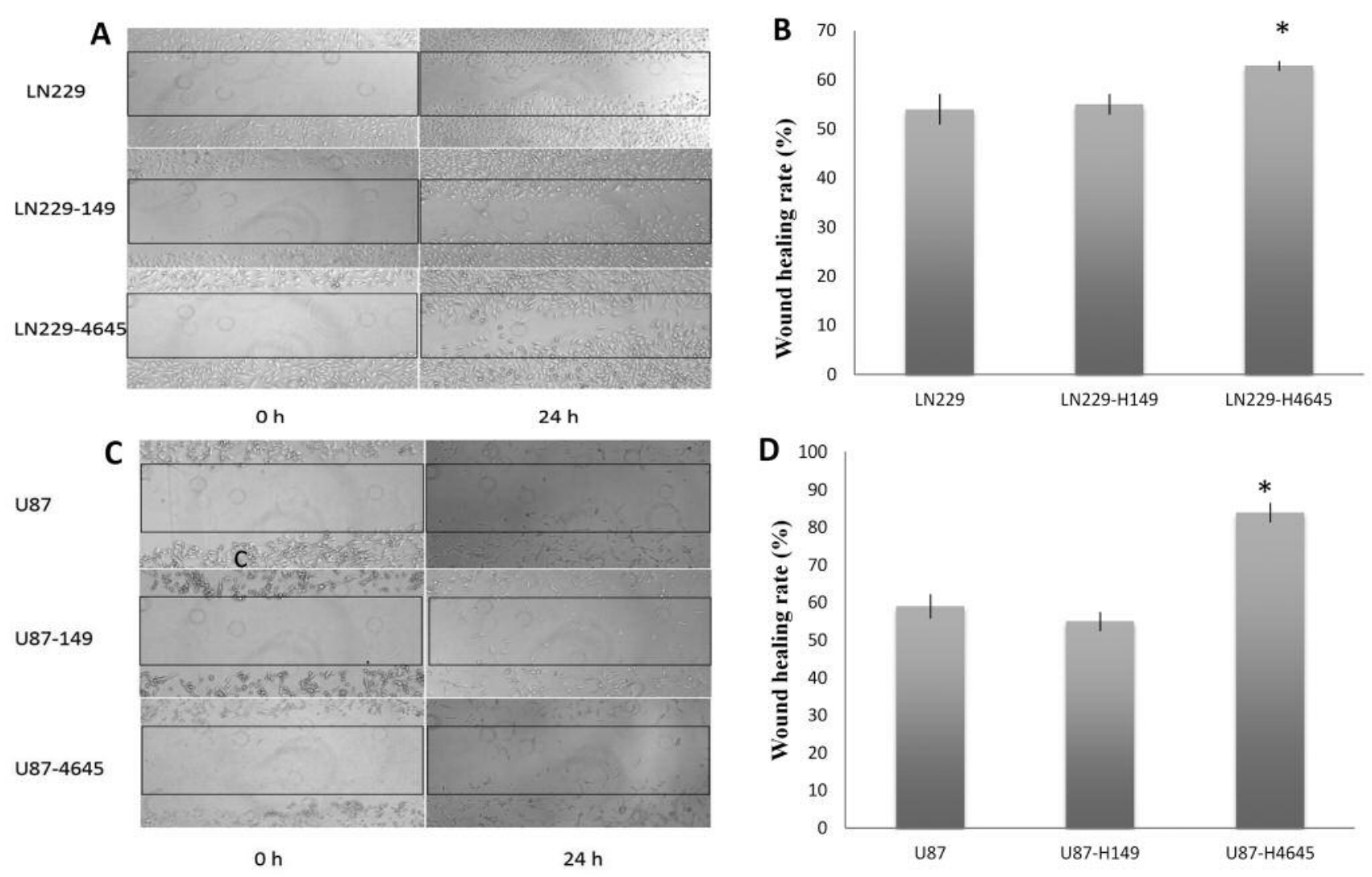

Figure 6. Effect of moesin up-regulation on glioblastoma cell invasion and migration in the wound-healing assay (A). Representative images of migrating LN229, LN229-H149 and LN229-H4645 cells, respectively. (B) Quantification of the migrating cells in each LN229 cell group. (C) Representative images of migrating U87, U87-H149 and U87-H4645 cells, respectively. (D) Quantification of the migrating cells in each U87 cell group. All images were obtained at $\times 200$ magnification. ${ }^{*} p<0.01$, when compared with untransfected and vector control cell group.

targeting moesin may represent a novel and effective strategy for preventing glioblastoma progression.

\section{Conflicts of Interest}

None of the Authors has a conflict of interest in regard to this study.

\section{Acknowledgements}

This work was mainly supported by Clinical Special Fund of Science and Technology of Jiangsu Province (No.BL2013006); the fund for six talent projects of Jiangsu Province (No.WSW-063); the fund for "333" high-level talent training project of Jiangsu Province (No. BRA2015051).

\section{References}

1 Bonavia R, Inda MM, Cavenee WK and Furnari FB: Heterogeneity maintenance in glioblastoma: A social network. Cancer Res 71: 4055-4060, 2011.

2 Mao H, Lebrun DG, Yang J, Zhu VF and Li M: Deregulated signaling pathways in glioblastoma multiforme: Molecular mechanisms and therapeutic targets. Cancer Invest 30: 48-56, 2012.
3 Stupp R, Hegi M E, van den Bent MJ, Mason WP, Weller M, Mirimanoff RO, Cairncross JG; European Organisation for Research and Treatment of Cancer Brain Tumor and Radiotherapy Groups; National Cancer Institute of Canada Clinical Trials Group: Changing paradigms - An update on the multidisciplinary management of malignant glioma. Oncologist 11: 165-180, 2006.

$4 \mathrm{Ng}$ SS, Cheung YT, An XM, Chen YC, Li M, Li GH, Cheung W, Sze J, Lai L, Peng Y, Xia HH, Wong BC, Leung SY, Xie D, He ML, Kung HF and Lin MC: Cell cycle-related kinase: A novel candidate oncogene in human glioblastoma. J Natl Cancer Inst 99: 936-948, 2007.

5 Xia H, Qi Y, Ng SS, Chen X, Li D, Chen S, Ge R, Jiang S, Li G, Chen Y, He ML, Kung HF, Lai L and Lin MC: MicroRNA$146 \mathrm{~b}$ inhibits glioma cell migration and invasion by targeting MMPs. Brain Res 1269: 158-165, 2009.

6 Pham MH, Zada G, Mosich GM, Chen TC, Giannotta SL, Wang $\mathrm{K}$ and Mack WJ: Molecular genetics of meningiomas: A systematic review of the current literature and potential basis for future treatment paradigms. Neurosurg Focus 30: E7, 2011.

7 Nakada M, Nakada S, Demuth T, Tran NL, Hoelzinger DB and Berens ME: Molecular targets of glioma invasion. Cell Mol Life Sci 64: 458-478, 2007. 
8 Canadian Cancer Society's Steering Committee: Canadian Cancer Statistics 2010. Toronto: Canadian Cancer Society; 2012. http://www.cancer.ca/statistics.

9 Dvorak HF, Weaver VM, Tlsty TD and Bergers G: Tumor microenvironment and progression. J Surg Oncol 103: 468-474, 2011.

10 Tsukita S and Yonemura S: ERM proteins: Head-to-tail regulation of actin-plasma membrane interaction. Trends Biochem Sci 22: 53-58, 1997.

11 Speck O, Hughes SC, Noren NK, Kulikauskas RM and Fehon RG: Moesin functions antagonistically to the Rho pathway to maintain epithelial integrity. Nature 421: 83-87, 2003.

12 Bretscher A: Regulation of cortical structure by the ezrinradixinmoesin protein family. Curr Opin Cell Biol 11: 109-116, 1999.

13 Carmeci C, Thompson DA, Kuang WW, Lightdale N, Furthmayr $\mathrm{H}$ and Weigel RJ: Moesin expression is associated with the estrogen receptor-negative breast cancer phenotype. Surgery 124: 211-217, 1998.

14 Charafe-Jauffret E, Monville F, Bertucci F, Esterni B, Ginestier C, Finetti P, Cervera N, Geneix J, Hassanein M, Rabayrol L, Sobol H, Taranger-Charpin C, Xerri L, Viens P, Birnbaum D and Jacquemier J: Moesin expression is a marker of basal breast carcinomas. Int J Cancer 121: 1779-1785, 2007.

15 Cui Y, Wu J, Zong M, Song G, Jia Q, Jiang J and Han J: Proteomic profiling in pancreatic cancer with and without lymph node metastasis. Int J Cancer 124: 1614-1621, 2009.

16 Estecha A, Sanchez-Martin L, Puig-Kroger A, Bartolome RA, Teixido J, Samaniego R and Sánchez-Mateos P: Moesin orchestrates cortical polarity of melanoma tumour cells to initiate 3D invasion. J Cell Sci 122: 3492-3501, 2009.

17 Ou-Yang M, Liu HR, Zhang Y, Zhu X and Yang Q: ERM stable knockdown by siRNA reduced in vitro migration and invasion of human SGC-7901 cells. Biochimie 93: 954-961, 2011.

18 Wu M, Liu D-Y, Yuan X-R, Liu Q, Jiang X-J, Yuan D, Huang J, Li X-J and Yang Z-Q: The expression of moesin in astrocytoma: Correlation with pathologic grade and poor clinical outcome. Med Oncol 30: 372, 2013.

19 Tynninen O, Carpen O, Jaaskelainen J, Paavonen T and Paetau A: Ezrin expression in tissue microarray of primary and recurrent gliomas. Neuropathol Appl Neurobiol 30: 472-477, 2004.
20 Nabors LB: Targeted molecular therapy for malignant gliomas. Curr Treat Options Oncol 5: 519-526, 2004.

21 Chen SD, Song MM, Zhong ZQ, Li N, Wang PL, Cheng S, Bai RX and Yuan HS: Knockdown of radixin by RNA interference suppresses the growth of human pancreatic cancer cells in vitro and in vivo. Asian Pac J Cancer Prev 13: 753-759, 2012.

22 Qin JJ, Wang JM, Du J, Zeng C, Han W, Li ZD, Xie J and Li GL: Radixin knockdown by RNA interference suppresses human glioblastoma cell growth in vitro and in vivo. Asian Pac J Cancer Prev 15: 9805-9812, 2014.

23 Sun GY, Wu JX, Wu JS, Pan YT and Jin R: Caveolin 1, E cadherin and $\beta$-catenin in gastric carcinoma, precancerous tissues and chronic non atrophic gastritis. Chin J Cancer Res 24: $2328,2012$.

24 Kyuno D, Yamaguchi H, Ito T, Kono T, Kimura Y, Imamura M, Konno T, Hirata K, Sawada N and Kojima T: Targeting tight junctions during epithelial to mesenchymal transition in human pancreatic cancer. World J Gastroenterol 20: 10813 10824, 2014.

25 Bao J, Wang S, Gunther LK, Kitajiri SI, Li C and Sakamoto T: The actin bundling protein TRIOBP 4 and 5 promotes the motility of pancreatic cancer cells. Cancer Lett 356: 367 373, 2015.

26 Wang $\mathrm{Z}$ and Ma Q: Beta catenin is a promising key factor in the SDF 1/CXCR4 axis on metastasis of pancreatic cancer. Med Hypotheses 69: 816 820, 2007.

27 Fuchs SY, Ougolkov AV, Spiegelman VS and Minamoto T: Oncogenic beta catenin signaling networks in colorectal cancer. Cell Cycle 4: 1522 1539, 2005.

28 Ji MY, Fan DK, Lv XG, Peng XL, Lei XF and Dong WG: The detection of EBP50 expression using quantum dot immunohistochemistry in pancreatic cancer tissue and down regulated EBP50 effect on PC 2 cells. J Mol Histol 43: 517 526, 2012.

29 Ji M, Fan D, Yuan L, Zhang Y, Dong W and Peng X: EBP50 inhibits pancreatic cancer cell growth and invasion by targeting the $\beta$-catenin/E-cadherin pathway. Exp Ther Med 10: 1311-1316, 2015. 